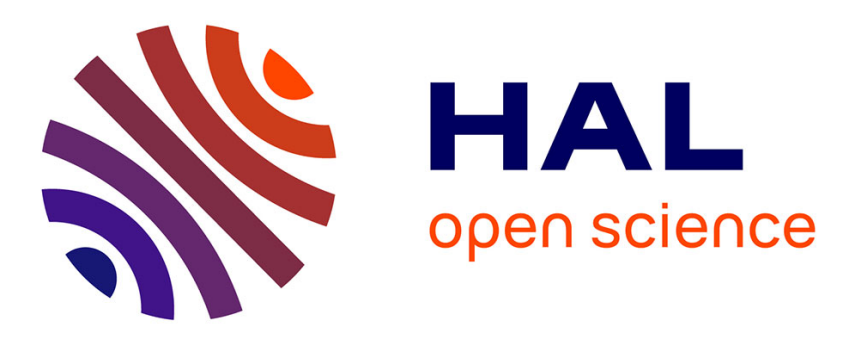

\title{
Hg concentrations and stable isotope variations in tropical fish species of a gold-mining-impacted watershed in French Guiana
}

Laure Laffont, Johanna Menges, Sylvaine Goix, Sophie Gentès, Régine Maury-Brachet, Jeroen Sonke, Alexia Legeay, Patrice Gonzalez, Raphaëlle Rinaldo, Laurence Maurice

\section{To cite this version:}

Laure Laffont, Johanna Menges, Sylvaine Goix, Sophie Gentès, Régine Maury-Brachet, et al.. Hg concentrations and stable isotope variations in tropical fish species of a gold-mining-impacted watershed in French Guiana. Environmental Science and Pollution Research, 2021, 28 (43), pp.60609-60621. 10.1007/s11356-021-14858-7 . hal-03434104

\section{HAL Id: hal-03434104 https://hal.science/hal-03434104}

Submitted on 25 Nov 2021

HAL is a multi-disciplinary open access archive for the deposit and dissemination of scientific research documents, whether they are published or not. The documents may come from teaching and research institutions in France or abroad, or from public or private research centers.
L'archive ouverte pluridisciplinaire HAL, est destinée au dépôt et à la diffusion de documents scientifiques de niveau recherche, publiés ou non, émanant des établissements d'enseignement et de recherche français ou étrangers, des laboratoires publics ou privés. 


\section{Hg concentrations and stable isotopes variations in tropical fish species of a}

\section{gold-mining impacted watershed in French Guiana}

Laure Laffont ${ }^{1, *}$, Johanna Menges ${ }^{2}$, Sylvaine Goix ${ }^{1,3}$, Sophie Gentès ${ }^{4}$, Régine Maury-Brachet ${ }^{4}$, Jeroen E. Sonke ${ }^{1}$, Alexia Legeay ${ }^{4}$, Patrice Gonzalez ${ }^{4}$, Raphä̈lle Rinaldo ${ }^{5}$, Laurence Maurice ${ }^{1, *}$

1 - Geosciences Environnement Toulouse, CNRS/IRD/CNES/Université Paul Sabatier, 14 avenue Edouard Belin, 31400 Toulouse, France

2 - Section 4.6, Geomorphology, GFZ-German Research Centre for Geosciences, 14473 Potsdam, Germany

3 - University Paul Sabatier, 14 avenue Edouard Belin, 31400 Toulouse, France

4 - EPOC, EPHE, Univ. Bordeaux, CNRS, 33120 Arcachon, France

5 - Parc Amazonien de Guyane, 1 rue Lederson 97354 Remire-Montjoly, France

*Corresponding authors: laure.laffont@get.omp.eu; laurence.maurice@ird.fr

ORCID numbers: 0000-0001-5850-7937 (L. Laffont), 0000-0001-7223-4787 (J. Menges), 00000002-5392-793X (S. Gentes), 0000-0001-7146-3035 (J. Sonke), 0000-0002-1052-142X (A. Legeay), 0000-0003-2628-2993 (P. Gonzalez), 0000-0003-3482-3892 (L. Maurice)

Key words: mercury, gold-mining, French Guiana, fish, stable isotopes, methylmercury

\section{Abstract:}

The aim of the study was to determine if gold mining activities could impact the mercury $(\mathrm{Hg})$ concentrations and isotopic signatures in freshwater fish consumed by riparian people in French Guiana. Total $\mathrm{Hg}, \mathrm{MeHg}$ concentrations and $\mathrm{Hg}$ stable isotopes ratios were analyzed in fish muscles from different species belonging to three feeding patterns (herbivorous, periphytophagous and 
piscivorous). We compared tributaries impacted by gold-mining activities (Camopi, CR) with a pristine area upstream (Trois-Sauts, TS), along the Oyapock River. We measured $\delta^{15} \mathrm{~N}$ and $\delta^{13} \mathrm{C}$ to examine whether $\mathrm{Hg}$ patterns are due to differences in trophic level. Differences in $\delta^{15} \mathrm{~N}$ and $\delta^{13} \mathrm{C}$ values between both studied sites were only observed for periphytophagous fish, due to difference of $\mathrm{CN}$ baselines, with enriched values at $\mathrm{TS}$. Total $\mathrm{Hg}$ concentrations and $\mathrm{Hg}$ stable isotopes fractionations showed that $\mathrm{Hg}$ accumulated in fish from both areas have undergone different biogeochemical processes. $\Delta^{199} \mathrm{Hg}$ variation in fish $(-0.5$ to $0.2 \%$ ) was higher than the ecosystem baseline defined by a $\Delta^{199} \mathrm{Hg}$ of $-0.66 \%$ in sediments, and suggested limited aqueous photochemical MeHg degradation. Photochemistry-corrected $\delta^{202} \mathrm{Hg}$ in fish were $0.7 \%$ higher than the baseline, consistent with biophysical and chemical isotope fractionations in aquatic environment. While $\mathrm{THg}$ concentrations in periphytophagous fish were higher in the gold-mining area than in TS, the ensemble of $\mathrm{Hg}$ isotope shifts in fish is affected by the difference of biotic (methylation/demethylation) and abiotic (photochemistry) processes between both areas and did therefore not allow to resolve the contribution of gold-mining related liquid $\mathrm{Hg}(0)$ in fish tissues. Mercury isotopes of $\mathrm{MeHg}$ in fish and lower trophic level organisms can be complementary to light stable isotope tracers.

\section{Introduction}

Mercury $(\mathrm{Hg})$ is a global pollutant which can induce serious health effects on living organisms depending on its concentration and speciation. The key neurotoxic form of $\mathrm{Hg}$ is methylmercury $(\mathrm{MeHg})$ which is produced naturally in aquatic environments by microorganisms (Guimarães et al., 1998; Roulet et al., 2000, 2001; Fleming et al., 2006; Kerin et al., 2006). MeHg is then bioaccumulated and biomagnified along the trophic chain (Mason et al., 1995; Maurice-Bourgoin et al., 1999; Kwon et al., 2012a, Chen et al., 2014) resulting in highly elevated MeHg concentrations in large predator fish (Roulet et al., 2000, 2001, Maury-Brachet et al., 2006). Fish consumption is a major pathway of human exposure to $\mathrm{MeHg}$ which can lead to severe health effects such as trembling, eyesight problems, coordination disorders, defects and ultimately death (WHO, 1990). It is therefore important to understand how $\mathrm{MeHg}$ is generated and incorporated into the food webs and identify its main sources to the food web. 

(Maurice-Bourgoin et al., 1999 and 2000, Mergler et al., 2007). In French Guiana, the regular consumption of local fish leads to elevated $\mathrm{Hg}$ concentrations in blood and hair of the local population exceeding the World Health Organization (WHO, 1990) safety limit $\left(10 \mu \mathrm{g} . \mathrm{g}^{-1}\right)$ (Cordier et al., 1998, Fréry et al., 2001). Neurodevelopmental investigations among MeHg-exposed children in French Guiana also showed significant links between mercury concentrations and the presence of neurological deficiencies (Cordier et al., 2002). The main sources of $\mathrm{Hg}$ to the aquatic environment (and ultimately humans) in French Guiana are small-scale gold mining activities and the erosion of tropical soils. Small- and large-scale gold mining activities are the largest $\mathrm{Hg}$ emission source (>55\%) in South America (Pacyna et al., 2010). The gold mining activities have been greatly enhanced by the increase of the gold price since 1980. Over the last decade gold mining has dramatically impacted the environment by increasing deforestation, soil erosion, surface water turbidity as well as the fishing and hunting pressure (Rimbaud et al., 2017). Large parts of the gold mining operations are clandestine and not controlled by the government. The total gold exploitation in French Guiana has been estimated at 5 to 10 tons per year by the WWF (World Wildlife Fund for Nature, 2018). The mean ratio of "liquid Hg used" to "gold produced" is estimated to be 5 (AMAP/UN, 2019) leading to an estimation of 25 to 50 tons per year of liquid $\mathrm{Hg}$ used for the amalgamation process in this region. Even though the liquid $\mathrm{Hg}$ used by small-scale gold-miners is partly recovered by retorting, large quantities of elemental $\mathrm{Hg}$ are liberated into the environment, both as vapor emitted to the atmosphere and in its liquid form directly released into soils and sediments (Velásquez-López, P. C., 2010). These locally Hgcontaminated soils and sediments, but also natural and non-gold mining anthropogenic $\mathrm{Hg}$ from soils, can then be transferred to the aquatic environment (Meech et al., 1997; Roulet et al., 2000; Dominique et al., 2007a and b; Goix et al., 2019). The speciation processes of liquid Hg were investigated in a freshwater indoor micro-cosmos which revealed $\mathrm{Hg}$ transfer between $\mathrm{Hg}^{0}$ droplets and water column, leading to the formation of aqueous $\mathrm{Hg}$ (II) and subsequently MeHg (Dominique et al., 2007a). However, there is no data on natural settings. The direct impact of liquid Hg released during gold mining activities on the aquatic food chain and subsequently on the local population remains few documented (Telmer et al., 2006, Marshall et al., 2018). Soil run-off is an important source of $\mathrm{Hg}$ to 
the hydrosystems. In this region, soils are characterized by elevated organic matter (around $60 \mu \mathrm{g} . \mathrm{g}^{-1}$ in the upper horizon in Grimaldi et al., 2008 and Guedron et al., 2006) and clay content and are enriched in Al- and Fe-oxyhydroxydes with a high storage capacity for $\mathrm{Hg}$ (Roulet et al., 1998, 2000; Grimaldi et al., 2008; Guedron et al., 2006, 2009). These soils accumulated atmospheric Hg deposition of natural and anthropogenic origin over thousands of years resulting in medium to high $\mathrm{Hg}$ concentrations ranging from 0.029 to $0.100 \mu \mathrm{g} \cdot \mathrm{g}^{-1}$ (Goix et al., 2019). Basically, these values are in the low or medium end of the concentration of contaminated soil (Guedron et al., 2006).

The variation in the natural abundances of $\mathrm{Hg}$ stable isotopes has become a widely used tool during the last few years (Blum, 2011, Sonke and Blum, 2013). Mercury has seven stable isotopes with nominal masses of 196, 198, 199, 200, 201, 202, and 204 and their isotopic variation can be used to identify and trace biogeochemical pathways in analogy to stable isotopes of lighter elements.

$\mathrm{Hg}$ isotope variations can be explained by mass-dependent fractionation (MDF) and massindependent fractionation (MIF). MDF is proportional to the mass difference of the Hg isotopes and occurs during redox transformations, biological cycling, and volatilization of $\mathrm{Hg}$ (Bergquist and Blum, 2009). MIF is predominantly associated with odd numbered $\mathrm{Hg}$ isotopes $\left({ }^{199} \mathrm{Hg}\right.$ and $\left.{ }^{201} \mathrm{Hg}\right)$ and only induced by a few transformation reactions. The ratio between anomalies $\Delta^{199} \mathrm{Hg}$ and $\Delta^{201} \mathrm{Hg}$ (defined as the difference between measured $\delta^{199} \mathrm{Hg}$ or $\delta^{201} \mathrm{Hg}$ and theoretical $\delta^{199} \mathrm{Hg}$ or $\delta^{201} \mathrm{Hg}$ calculated from mass dependent fractionation only) appears characteristic of two known processes which result in MIF: the nuclear volume effect or the magnetic isotope effect which occurs during photochemical radical pair reactions (Estrade et al., 2009; Bergquist and Blum, 2007). However, in the environment MIF introduced by magnetic isotope effect induced by photochemical reactions is predominant relative to MIF by nuclear volume effect (Blum, 2011, Sonke, 2011). As $\Delta^{199} \mathrm{Hg}$ and $\Delta^{201} \mathrm{Hg}$ signatures remain unchanged during non-photochemical transport or transfer processes, they are especially useful to trace sources, when we know the $\mathrm{Hg}$ isotopic signatures, including MIF, of sources, and photochemical transformations of $\mathrm{Hg}$ in the environment. More recently, MIF on even isotope ${ }^{200} \mathrm{Hg}$ has been observed and is measured as anomaly $\Delta^{200} \mathrm{Hg}$ (defined as the difference between measured $\delta^{200} \mathrm{Hg}$ and theoretical $\delta^{200} \mathrm{Hg}$ calculated from mass dependent fractionation only). It is used to 
discriminate between two atmospheric sources: dry and wet deposits. First have negative $\Delta^{200} \mathrm{Hg}$ mostly representative of GEM signature while wet deposition exhibits positive $\Delta^{200} \mathrm{Hg}$ (Gratz et al., 2010; Demers et al., 2013 and 2015; Lepak et al., 2015; Yin et al., 2016; Fu et al., 2016 and Obrist et al., 2017).

MDF with a large range of $\delta^{202} \mathrm{Hg}$ is observed in natural samples and in many natural samples anomalies signatures have also been reported (Blum et al., 2014). Bergquist and Blum (2007) observed large positive odd-isotopes anomalies during the experimental photochemical degradation of inorganic $\mathrm{Hg}(\mathrm{IHg})$ and $\mathrm{MeHg}$ as well as in natural fish samples. They ascribed the fractionation during the photochemical reaction and suggested that the complementary odd-isotopes signatures of the residual $\mathrm{MeHg}$ in water gets conservatively incorporated into the food web and can therefore be observed in the fish samples. As explained by Tsui et al., odd-isotopes anomalies are likely attributable to differences in diet or \% MeHg (Tsui et al., 2012). In a variety of other studies, no indication of in vivo MIF was observed (Gantner et al., 2009; Perrot et al., 2010, 2012; Senn et al., 2010). Hg isotopes have been analyzed in high-trophic level biota to reflect the $\mathrm{Hg}$ isotope values of $\mathrm{MeHg}$ in the ambient environment as trophic fractionation of $\mathrm{Hg}$ isotopes in the lower trophic levels is not significant for $\mathrm{Hg}$ (II) and $\mathrm{MeHg}$ (Tsui et al., 2020). Kwon et al. (2012b) conducted two controlled experiments to evaluate MDF and MIF during trophic transfer into fish. They found no indication of isotopic fractionation and suggested that stable $\mathrm{Hg}$ isotope ratios in fish can be used to trace environmental sources of $\mathrm{Hg}$ in aquatic ecosystems. More recently, in Tsui et al. review (2020), authors suggested that $\mathrm{Hg}$ isotopes signature, especially odd-MIF, can increase with river size due to reduction in canopy cover which induces increase of photochemistry of $\mathrm{Hg}$ and $\mathrm{MeHg}$ (Tsui et al., 2013).

It is the case of areas impacted by goldmining activities, miners use liquid elemental mercury for the gold amalgamation with a known isotopic signature of mercury (Laffont et al., 2011; Goix et al., 2019). This includes $\operatorname{Hg}(0)$ vapor produced by amalgam burning which could be transported in the atmosphere, reduced and redeposited with the precipitation in the forest (foliage, soils, etc.). Actually, Grimaldi et al. 2015 showed that redeposition of $\mathrm{Hg}(0)$ vapor after amalgam burning in upper tropical 
soils is minor relative to natural $\mathrm{Hg}$. However, natural mercury from pristine sediments showed a different isotopic signature than in gold-mined area (Goix et al., 2019). Mercury inputs in sediments as well as in water column, from natural and from goldmining activities, undergo physico-bio-chemical processes in the hydrosystem (desorption/sorption of mercury between liquid and solid phase, absorption/methylation/demethylation in aquatic organisms, and photochemistry in surface water) that induce isotopes fractionation which are highly dependent of the environment; for example, the MIF signature in macroinvertebrates and fish is mediated by the effect of canopy on in-stream photodemethylation (Tsui et al., 2013). The knowledge of the fractionations induced by each of these processes can help to discriminate between the different sources of mercury for identical environmental conditions.

To understand the feeding relationships among consumers in a food web, carbon and nitrogen stable isotopes analysis are recognized as relevant tools (Layman et al. 2012). Indeed, nitrogen incorporation by organisms leads to an enrichment in $\delta^{15} \mathrm{~N}$ of approximately 3 to $5 \%$ o between each trophic level (Cabana \& Rasmussen,1994; Zanden et al. 2001; Caut et al. 2009), allowing the trophic position of species to be inferred. In contrast, the relatively low enrichment of $\delta^{13} \mathrm{C}$ along food chains ( 0 to $1 \%$ between two trophic levels) enables discriminating the different sources of organic carbon (Hobson et al. 2002. Neres-Lima et al. 2017).

The main objective of the present study was to determine if gold mining activities impact the $\mathrm{Hg}$ concentrations and isotopic signatures of tropical fish species. We studied the Oyapock river basin in French Guiana characterized by a pristine (Trois-Sauts, TS) and a gold mining (Camopi River, CR) area. Specific objectives were: i) to better understand the underlying processes of $\mathrm{Hg}$ stable isotopes fractionation in fish species from three different feeding patterns and ii) to assess if $\mathrm{Hg}$ isotopes signatures can be used to distinguish anthropogenic from natural $\mathrm{Hg}$ in fish muscle, mainly in biofilmeating fish species. In the frame of the same project (RIMNES research program), Goix et al. (2019) analyzed sediments sampled at the same time and in the same locations than the fish results presented in this article. Our team showed that $\mathrm{Hg}$ isotopes distinguish both sources of $\mathrm{Hg}$ in sediments and 
revealed that release of liquid mercury from gold-mining activities directly impact locally exploited rivers.

Fish samples with different feeding ecology (herbivorous, periphytophagous and piscivorous) have been analyzed for total $\mathrm{Hg}$ and nitrogen $\left(\delta^{15} \mathrm{~N}\right)$ and carbon $\left(\delta^{13} \mathrm{C}\right)$ stable isotopes, while $\mathrm{MeHg}$ concentrations have been determined in periphytophagous fish and $\mathrm{Hg}$ stable isotopes have been measured in periphytophagous and piscivorous fish species. Samples were collected in two sub-basins of the Oyapock River, in French Guiana: the Oyapock river upstream at Trois-Sauts village, and the Camopi river, respectively in pristine and gold-mining areas.

\section{Methods}

\subsection{Study area}

Our studied area is located in the Oyapock basin at the eastern part of French Guiana, at the Brazilian border (Figure 1). The Oyapock River (404 km long) originates in the Tumuk Humak Mountains and runs northward towards the Atlantic Ocean. Its mean annual discharge reaches $800 \mathrm{~m}^{3}$ $\mathrm{s}^{-1}$ at the hydrological gauging station close to Saint Georges. Samples were collected $50 \mathrm{~km}$ upstream at Camopi village and $250 \mathrm{~km}$ upstream at Trois Sauts villages. At the Camopi village, the Camopi River (secondary stream), one of its main tributaries, joins the Oyapock River (primary stream). The Camopi River basin is affected by artisanal and small-scale gold mining activities (ASGM) since the 19th century. Nowadays a recent rise in ASGM has been reported on small creeks upstream (tertiary streams), in the Camopi River basin, and on the Oyapock River basin downstream of the confluence with the Camopi River (Parc Amazonien de Guyane, PAG 2017; Rahm et al. 2017). The pristine region of Trois Sauts lies on the Oyapock River $110 \mathrm{~km}$ upstream of the Camopi confluence and no gold mining activities have been reported in this area (Gentès et al. 2019).

\subsection{Sampling}

Fish samples were collected in the Oyapock watershed during the low water stage, in the Camopi river in October 2013 (Hg-contaminated sites impacted by gold mining activities) and in the Oyapock river upstream in October 2012 (the pristine area of Trois Sauts), with the help of local 
fishermen. Different fishing techniques were used such as nets and fish lines. Following the protocol of Maury-Brachet et al. (2006), fish were dissected on site with a clean stainless steel scalpel and Teflon dissecting forceps and flesh samples were collected. The standard length (cm) and total fresh weight $(\mathrm{g})$ of each individual were measured immediately. Fish samples were frozen in the field using a generator-powered freezer and shipped to GET and EPOC laboratories under dry ice, with final storage in the laboratory at $-80^{\circ} \mathrm{C}$. Before further analyses, samples were freeze-dried and manually ground to homogenize in an agate mortar.

For the purpose of this study, two piscivorous (Hoplias aimara and Boulengerella cuvieri), two periphytophagous (Pseudoancistrus barbatus and Hypostomus gymnorhynchus) and two herbivorous (Myloplus rubripinnis and Myloplus ternetzi) species were selected because 1) they are well represented in the Amazon basin (Le Bail et al. 2012); 2) they are regularly consumed by the local population (Fréry et al. 2001) and therefore represent the main $\mathrm{Hg}$ exposure pathway; 3) they represent different trophic levels and have a well-known and specific diet (Keith et al., 2000, Le Bail et al., 2000; Durrieu et al., 2005, Maury-Brachet et al., 2006).

The feeding ecology of both piscivorous fish species are mainly fish of varying size, giving them a high trophic position in the food web (see trophic position calculation in results part). Moreover, Hoplias aimara was proposed as a bioindicator species for $\mathrm{Hg}$ (Durrieu et al., 2005; Gentès et al. 2019). Piscivorous fish were selected by length. H. aimara specimen with standard length less than $38 \mathrm{~cm}$ could be mistaken with another species (H. malabaricus). Small B. cuvieri individuals (standard length $<40 \mathrm{~cm}$ ) are juveniles and their diet is different from that of adult fish. Consequently, we selected $H$. aimara $>38 \mathrm{~cm}$ and B. cuvieri $>40 \mathrm{~cm}$ for analysis.

Periphytophagous fish species are benthic primary consumers and consume exclusively periphyton or biofilms on hard substrates (like rocks or immersed tree trunks, etc.). Periphyton is an important food source for the food web, even when its biomass is low (Lamberti, 1996). Moreover, periphyton has been identified as the principal entry point for methylmercury in an Amazonian region (Roulet et al., 2000). Indeed, several studies have shown that periphyton supports high $\mathrm{Hg}$ methylation 
rates due to microbial activity in tropical ecosystems (Guimarães et al., 1998; Acha et al., 2005, Klaus et al. 2016).

The both chosen herbivorous species feed exclusively on terrestrial materials from the river banks (leaves, flowers, fruits) and provide information about pelagic primary consumers (Planquette et al., 1996).

\subsection{Chemical analysis}

\subsubsection{Nitrogen and carbon stable isotopes analysis}

We measured nitrogen and carbon ratios in muscles of herbivorous, periphytophagous and piscivorous fish species. All samples were dried and reduced to powder and $0.5 \mathrm{mg}$ were weighed and placed in tin capsules (purity 99.998\%) and then analyzed using a continuous flow isotope ratio mass spectrometer in Toulouse (Elemental Microanalysis, UK) in Ecolab laboratory (France). The Isoprime 100 spectrometer is coupled in continuous flow mode using pure helium as gas vector to an elemental analyzer Micro Vario for solids combustion. A dual inlet injection system introduces the reference gases $\left(\mathrm{N}_{2}\right.$ and $\left.\mathrm{CO}_{2}\right)$.

The ${ }^{13} \mathrm{C} /{ }^{12} \mathrm{C}\left(\right.$ denoted $\left.\delta^{13} \mathrm{C}\right)$ and ${ }^{15} \mathrm{~N} /{ }^{14} \mathrm{~N}\left(\right.$ denoted $\left.\delta^{15} \mathrm{~N}\right)$ ratios, expressed in \%o, were calculated as the relative differences between the sample and the conventional standard following Peterson and Fry (1987):

$$
\delta^{15} \mathrm{~N} \text { or } \delta^{13} \mathrm{C}(\%)=[(\text { Rsample}- \text { Rstandard }) / \text { Rstandard }] \times 1,000(\text { Eq. } 1)
$$

where $\mathrm{R}$ is ${ }^{13} \mathrm{C} /{ }^{12} \mathrm{C}$ or ${ }^{15} \mathrm{~N} /{ }^{14} \mathrm{~N}$ (Peterson and Fry, 1987). The international reference material standard is atmospheric $\mathrm{N}_{2}$ for nitrogen and Vienna Pee Dee Belemnite for carbon.

Standards were run in duplicate every twenty measurements. Three internal standards of urea, alanine and acetanilid were analyzed. The obtained average values were $\delta^{15} \mathrm{~N}=-0.45 \pm 0.14 \%$ and $\delta^{13} \mathrm{C}=-36.33 \pm 0.26 \%(\mathrm{n}=9,2 \mathrm{SD})$ for urea, $\delta^{15} \mathrm{~N}=8.38 \pm 0.23 \%$ and $\delta^{13} \mathrm{C}=-23.03 \pm 0.18 \%$ o $(\mathrm{n}=$ 6, 2SD) for alanine and $\delta^{15} \mathrm{~N}=-3.89 \pm 0.46 \%$ and $\delta^{13} \mathrm{C}=-33.29 \pm 0.14 \%(\mathrm{n}=6,2 \mathrm{SD})$ for acetanilid. The highest analytic precisions were $0.46 \%$ for $\delta^{15} \mathrm{~N}$ and $0.26 \%$ for $\delta^{13} \mathrm{C}(2 \mathrm{SD})$. 
Measured $\mathrm{C} / \mathrm{N}$ ratios provide an indication of the fat content in the tissue analyzed (Post et al.

2007). Because lipids are ${ }^{13} \mathrm{C}$-depleted relative to proteins, high lipid content (with $\mathrm{C} / \mathrm{N}>4$ ) in organisms affects measured $\delta^{13} \mathrm{C}$ ratios. In our study, all organisms had a $\mathrm{C} / \mathrm{N}<4$, thus not requiring lipid extraction.

\subsubsection{Total $\mathrm{Hg}$ concentrations}

Fish samples were immediately stored in sealed polyethylene bags and frozen at $-18{ }^{\circ} \mathrm{C}$. Back to the laboratories, they were freeze-dried and analyzed a couple of months after sampling. Total $\mathrm{Hg}$ concentrations ( $\mathrm{THg}$ ) were measured on 108 fish muscle samples, using an Advanced Mercury Analyzer (AMA254) (GET laboratory). Each sample was combusted inside the AMA at $750^{\circ} \mathrm{C}$ for 150 seconds. The released $\mathrm{Hg}$ was trapped in a gold trap and subsequently released and measured with an integrated atomic absorption spectrometer. The accuracy of the measurements was assigned by the analysis of certified reference materials ERM-CE464 (tuna fish) and DOLT4 (dogfish liver) (for the piscivorous fish species) as well as TORT 2 (lobster hepatopancreas) for the less concentrated periphytophagous fish species.

The measured concentrations for the reference materials were in agreements with the certified values for TORT2 $\left(\mathrm{THg}=0.307 \pm 0.004 \mu \mathrm{g} \cdot \mathrm{g}^{-1} ; \mathrm{n}=6\right.$; recovery: $\left.114 \%\right)$ and DOLT4 $(\mathrm{THg}=2.385 \pm$ $0.003 \mu \mathrm{g} \cdot \mathrm{g}^{-1} ; \mathrm{n}=4$; recovery : $\left.92 \%\right)$. For CE464 the recovery was $91 \pm 1 \%\left(4.757 \pm 0.208 \mu \mathrm{g} \cdot \mathrm{g}^{-1}, \mathrm{n}=\right.$ 3). Natural samples were all measured in duplicate. If the difference between the duplicate measurements was above 10\%, a third measurement was carried out. All THg concentrations are reported on a dry weight basis.

\subsubsection{Hg speciation analyses}

We assumed that \% MeHg in piscivorous fish is close to $100 \%$ (Maury-Brachet et al. 2006) and chose to not analyze mercury speciation of these samples. However, a number of nineteen muscle samples of periphytophagous fish and two certified reference materials, TORT2 and NIST2976, were analyzed. Speciation analyses have been made using double-spike species specific isotope dilution method with GC-ICP-MS detection at the GET laboratory (Monperrus et al. 2008). Subsamples of 200 mg were digested with $5 \mathrm{~mL}$ of TMAH in a microwave Discover SP-D (CEM society) with a ramp of 
2 min and constant heating during $4 \mathrm{~min}$ at $70^{\circ} \mathrm{C}$ and stirring (Navarro et al. 2011). After cooling, an aliquot of the extract was transferred to glass vials and $5 \mathrm{ml} \mathrm{HAc/NaAc}$ buffer solution (pH 3.9) was added to the aliquot. Then, an appropriate amount of isotopically enriched ${ }^{199} \mathrm{IHg}$ and ${ }^{201} \mathrm{MeHg}$ was

271

272 added to each sample (Monperrus et al, 2008). After letting the sample equilibrate for two hours, the $\mathrm{pH}$ was adjusted to $\mathrm{pH} 3.9$ using bi-distilled $\mathrm{HCl}$. The species were then propylated by adding $0.2 \mathrm{ml}$ of newly prepared Sodium-tetra(n-propyl)borate (NaBPr4) 10\% (w/v). Then, $2 \mathrm{ml}$ of hexane was added and each vial was manually shaken for $5 \mathrm{~min}$ to extract all the $\mathrm{Hg}$ species into the organic phase. An aliquot of the organic phase was then transferred into a GC-vial and kept frozen until analysis. The samples were analyzed using a GC (Thermo) coupled to a sector field ICP-MS (Thermo Element XR) at the GET laboratory. The measured yield of MeHg for the two reference materials, (58 $\%$ for TORT2 and $49 \%$ for NIST2976), are consistent with the certified values of $56 \%$ and $46 \%$, respectively. The average yield of the analysis was $98 \pm 8 \%$ quantified by comparison of the sum of the $\mathrm{MeHg}$ and $\mathrm{IHg}$ concentrations measured with the described method and THg analysis with AMA254.

\subsubsection{Hg stable isotope analyses}

Appropriate amounts of samples (0.5 g of periphytophagous fish muscle and $0.05 \mathrm{~g}$ of piscivorous fish muscle) were digested in $5 \mathrm{ml}$ inverse aqua regia $\left(\mathrm{HNO}_{3}\right.$ and $\left.\mathrm{HCl}, 3: 1 \mathrm{v}: \mathrm{v}\right)$ at $120^{\circ} \mathrm{C}$ for $4 \mathrm{~h}$ in closed glass vials on a heating plate. After cooling, $1 \mathrm{ml} \mathrm{of} \mathrm{H}_{2} \mathrm{O}_{2}$ was added and samples were heated again at $120^{\circ} \mathrm{C}$ for at least $4 \mathrm{~h}$. The average yield of the digestion was $103 \pm 6 \%$ for periphytophagous and $104 \pm 5 \%$ for piscivorous fish samples quantified by comparison of the results from the MC-ICP-MS and THg analysis with AMA254. In 2013-2014, our technical materials did not allow us to analyze $\mathrm{Hg}$ isotopes of herbivorous fish due to low $\mathrm{THg}$ concentration.

$\mathrm{Hg}$ stable isotope ratios were measured by continuous flow cold vapor generation (using Sn(II) reduction) multi collector inductively coupled plasma mass spectrometry (CV-MC-ICPMS, Thermo Finnigan Neptune, Germany) at the GET laboratory (Toulouse, France) according to previously published methods (Laffont et al., 2009, 2011; Masbou et al., 2013, 2014; Enrico et al., 2016). Instrumental mass bias was corrected by sample bracketing using the international $\mathrm{Hg}$ standard NIST SRM 3133 at matching concentrations (several sequences between 0.8 and 2.5 ppb depending 
on initial $\mathrm{THg}$ of fish) and prepared in the same matrix than samples. Hg isotopic composition is reported as $\delta$-values, which represents the deviation from the bracketing standard and expressed in permil (\%) using the following equation:

$$
\delta^{\mathrm{xxx}} \mathrm{Hg}=\left(\frac{\left(\frac{\mathrm{xxxHg}}{198 \mathrm{Hg}}\right)_{\text {sample }}}{\left(\frac{\mathrm{xxxHg}}{198 \mathrm{Hg}}\right)_{\text {SRM3133 }}}-1\right) * 1000 \text { (Eq. 2) }
$$

MIF is quantified as the $\delta$-value deviation from the theoretical MDF using the following equation:

$$
\Delta^{\mathrm{xxx}} \mathrm{Hg}=\delta^{\mathrm{xxx}} \mathrm{Hg}_{\text {sample }}-\beta * \delta^{202} \mathrm{Hg}_{\text {sample }} \text { (Eq. 3) }
$$

Where $\beta$-values for isotopes ${ }^{199} \mathrm{Hg},{ }^{200} \mathrm{Hg},{ }^{201} \mathrm{Hg}$ and ${ }^{204} \mathrm{Hg}$ are $0.252,0.502,0.752$, and 1.493 respectively according to the kinetic MDF law (Blum and Bergquist, 2007). Long-term reproducibility of Hg isotope measurements was assessed by analyzing two reference materials UM-Almaden and ETH in-house Fluka along with the samples at the same THg concentrations. The obtained values for UM-Almaden are $\delta^{202} \mathrm{Hg}=-0.52 \pm 0.14 \%, \Delta^{199} \mathrm{Hg}=-0.03 \pm 0.08 \%$ and $\Delta^{200} \mathrm{Hg}=0.03 \pm 0.04 \%$ o $($ mean $\pm 2 \mathrm{SD}, \mathrm{n}=7)$ and for ETH in-house Fluka $\delta^{202} \mathrm{Hg}=-1.53 \pm 0.14 \%, \Delta^{199} \mathrm{Hg}=-0.10 \pm 0.04$ and $\Delta^{200} \mathrm{Hg}=0.02 \pm 0.04 \% \quad($ mean $\pm 2 \mathrm{SD}, \mathrm{n}=14)$ and agree with previously published values (Blum and Bergquist, 2007; Smith et al., 2014). The certified reference materials TORT2 and ERM-CE464 were also analyzed. Measured isotopic compositions for reference materials are consistent with previously published values (Laffont et al., 2009; Masbou et al., 2013). Uncertainties applied to samples were the larger of either the 2SD on the ETH in-house Fluka or the 2SD on sample replicate when available and larger than the 2SD of ETH in-house Fluka.

\subsection{Data analysis}

\subsubsection{Trophic position calculation for piscivorous fish}

The position of an organism within a food chain can be deducted from the relatively constant $\delta^{15} \mathrm{~N}$ enrichment observed between each trophic level (Vander Zanden and Rasmussen, 1996). The trophic position (TP) of piscivorous fish was calculated based on $\delta^{15} \mathrm{~N}$ values and following the equation of Bergamino et al. (2011):

$$
\mathrm{TP}_{\mathrm{i}}=\left[\left(\delta^{15} \mathrm{~N}_{\mathrm{i}}-\delta^{15} \mathrm{~N}_{\mathrm{pc}}\right) / 3.4\right]+2(\mathrm{Eq} 4)
$$


where $\mathrm{TP}_{\mathrm{i}}$ represents the average position of species $\mathrm{i} ; \delta^{15} \mathrm{~N}_{\mathrm{i}}$ the average $\delta^{15} \mathrm{~N}$ value of species $\mathrm{i} ; \delta^{15} \mathrm{~N}_{\mathrm{pc}}$ the average $\delta^{15} \mathrm{~N}$ value of primary consumers; 3.4 the mean $\delta^{15} \mathrm{~N}$ trophic enrichment occurring per trophic level (Post, 2002); and 2, the trophic position of the baseline organism (= primary consumer, here herbivorous fish species were selected because they present the lowest $\delta^{15} \mathrm{~N}$ values, in comparison to periphytophagous fish, see result part 3.1).

\subsubsection{Statistical analysis}

Statistical analyses were done using $\mathrm{OR}$ (Version 3.4.4). Comparison tests were conducted with Wilcoxon (medians) as distribution is not normal and sample size low. A confidence level of 0.95 was chosen. Means or medians were considered to be significantly different when the $p$ value was less than 0.05 .

\section{Results}

These are first data of $\mathrm{THg}, \mathrm{MeHg}$ concentrations and stable $\mathrm{Hg}$ isotopes ratios for different fish species highly consumed in French Guiana by local population. All the results are detailed in the Supplementary information (Table S1).

\subsection{Nitrogen and carbon stable isotopes ratios in fish}

Carbon $\left(\delta^{13} \mathrm{C}\right)$ and nitrogen $\left(\delta^{15} \mathrm{~N}\right)$ stable isotopes individual values for herbivorous, periphytophagous and piscivorous fish from both sites are plotted in Figure 2. Results shown that the $\delta^{15} \mathrm{~N}$ is similar between two sites for piscivorous fish (Wilcoxon test, $\mathrm{W}=26, \mathrm{p}>0.05$ ), but not for periphytophagous fish which it is significantly different (Wilcoxon test, $\mathrm{W}=62, \mathrm{p}=0.013$ ) with higher values in TS $(10.8 \pm 0.6 \%, \mathrm{n}=12)$ than in $\mathrm{CR}(9.8 \pm 0.7 \%$, $\mathrm{n}=6)$. We cannot calculate a Wilcoxon test for herbivorous fish as $\mathrm{n}=5$ at CR but the average $\delta^{15} \mathrm{~N}$ is close for both site $(6.2 \pm 0.3$ $\%, \mathrm{n}=9$, at TS and $6.2 \pm 0.5 \%, \mathrm{n}=5$, at $\mathrm{CR}$ ). Trophic positions (TP) were $3.8 \pm 0.1$ and $3.9 \pm 0.1$ for piscivorous fish for CR and TS, respectively and were not statistically different between both sites (Wilcoxon test, $\mathrm{W}=0.94, \mathrm{p}=0.34$ ).

Periphytophagous fish present a variation of $\delta^{13} \mathrm{C}$ (Fig. 2) ranging from -30.5 to $-25.8 \%$ with an average of $-28.3 \pm 1.3 \%(n=12)$ at TS and from -24.0 to $-27.9 \%$ with an average of $-26.0 \pm 1.3 \%(n=$ 
6) at $\mathrm{CR}$, showing a slightly more positive $\delta^{13} \mathrm{C}$ at $\mathrm{CR}$ than TS (Wilcoxon test, $\mathrm{W}=7, \mathrm{p}=0.005$ ). The

$348 \delta^{13} \mathrm{C}$ values of herbivorous fish $(-27.2 \pm 0.2 \%, \mathrm{n}=9$, at TS and $-26.7 \pm 0.3 \%, \mathrm{n}=5$, at $\mathrm{CR})$ are very 349 close between both sites (Wilcoxon test not possible with $n=5$ ). Piscivorous fish $\delta^{13} \mathrm{C}$ values are also 350 statistically similar between both sites: $-26.2 \pm 0.5 \%(n=6)$ at TS and $-26.2 \pm 0.2 \%$ o $(n=6)$ at CR (Wilcoxon test, $\mathrm{W}=19, \mathrm{p}=0.94$ ).

\subsection{Total mercury concentrations in fish}

THg concentrations (Fig. 3) in herbivorous species $(n=36)$ vary between 0.006 and 0.037

$\mu \mathrm{g} . \mathrm{g}^{-1} \mathrm{dw}$ and are significantly higher at TS compared to CR $\left(0.022 \pm 0.006 \mu \mathrm{g} \cdot \mathrm{g}^{-1}\right.$ at TS and $0.012 \pm 0.008 \mu \mathrm{g} . \mathrm{g}^{-1}$ at $\mathrm{CR}$, Wilcoxon test, $\left.\mathrm{W}=276, \mathrm{p}=8.1 * 10^{-5}\right)$. In periphytophagous species $(\mathrm{n}=41)$, THg concentrations vary between 0.017 and $0.248 \mu \mathrm{g} \cdot \mathrm{g}^{-1} \mathrm{dw}$ and are significantly higher at CR relatively to TS $\left(0.13 \pm 0.05 \mu \mathrm{g} \cdot \mathrm{g}^{-1}\right.$ at TS and $0.20 \pm 0.04 \mu \mathrm{g} \cdot \mathrm{g}^{-1}$ at $\mathrm{CR}$, Wilcoxon test, $\mathrm{W}=28, \mathrm{p}=$ 0.003). In piscivorous species $(n=30)$, THg concentrations range from 0.216 to $6.346 \mu \mathrm{g}^{-g^{-1}} \mathrm{dw}$ and are not significantly different between CR and TS (average of $2.0 \pm 0.9 \mu \mathrm{g} . \mathrm{g}^{-1}$ at TS and $2.9 \pm 1.5 \mu \mathrm{g} . \mathrm{g}^{-1}$ at $\mathrm{CR}$, Wilcoxon test, $\mathrm{W}=65, \mathrm{p}=0.094)$. THg concentrations in all piscivorous fish samples (except one) exceeded the US EPA (2012) recommendation $\mathrm{THg}$ value of $0.256 \mu \mathrm{g} \cdot \mathrm{g}^{-1} \mathrm{dw}$ for a daily consumption of $0.113 \mathrm{~kg}(\mathrm{ww}) /$ day of fish for a pregnant women of $78 \mathrm{~kg}$.

\subsection{Methylmercury concentrations in fish}

The $\% \mathrm{MeHg}$ has only been measured in periphytophagous species because it reaches more than $95 \%$ in piscivorous study species (Maury-Brachet et al., 2006): it varies between 92 and $95 \%$ with a mean of $95 \pm 1 \%(1 \mathrm{SD}, \mathrm{n}=6)$ in $\mathrm{CR}$ and between 82 and $95 \%$ with a mean of $89 \pm 5 \%(1 \mathrm{SD}, \mathrm{n}$ $=13$ ) in $\mathrm{TS}$ (Table S1). The difference of \% MeHg between both locations is significant (Wilcoxon test, $\mathrm{W}=4, \mathrm{p}=0.0009$ ) with the $\% \mathrm{MeHg}$ higher at $\mathrm{CR}$. Moreover, we observe that the variance of $\% \mathrm{MeHg}$ is higher at TS than at CR (20.9 and 1.3 respectively, variance unity is the square of \%).

\subsection{Mercury isotopes signatures}

For periphytophagous fish, $\delta^{202} \mathrm{Hg}$ values vary between $-1.40 \%$ and $-0.89 \%$ (mean of $1.14 \pm 0.16 \%$ (1SD)) at TS and between $-1.41 \%$ and $-1.03 \%$ (mean of $-1.21 \pm 0.14 \%$ ) at CR. For 
373 piscivorous fish, $\delta^{202} \mathrm{Hg}$ values vary between $-1.68 \%$ and $-1.17 \%$ (mean of $-1.42 \pm 0.11 \%$ ) at TS and 374 between $-1.68 \%$ and $-0.95 \%$ (mean of $-1.29 \pm 0.21 \%$ ) at CR (Fig. 4). Regarding the stable $\mathrm{Hg}$ 375 isotopes anomalies, $\Delta^{199} \mathrm{Hg}$ values for periphytophagous vary between $-0.49 \%$ and $0.00 \%$ (mean of $3760.30 \pm 0.16 \%$ ) at TS and between $-0.60 \%$ and $0.20 \%$ (mean of $0.06 \pm 0.12 \%$ ) at CR. $\Delta{ }^{199} \mathrm{Hg}$ values 377 for piscivorous vary between $-0.50 \%$ and $-0.03 \%$ (mean of $-0.38 \pm 0.11 \%$ ) at TS and between -0.26 $378 \%$ and $-0.06 \%$ (mean of $-0.20 \pm 0.06 \%$ ) at CR (Fig. 4). Even isotope anomaly for periphytophagous 379 fish, $\Delta^{200} \mathrm{Hg}$, varies between $-0.09 \%$ and $-0.04 \%$ (mean of $-0.06 \pm 0.02 \%$ ) at TS and between -0.09

$380 \%$ and $-0.01 \%$ (mean of $-0.05 \pm 0.03 \%$ ) at CR. $\Delta^{200} \mathrm{Hg}$ values for piscivorous vary between $-0.08 \%$ 381 and $-0.04 \%$ (mean of $-0.06 \pm 0.01 \%$ ) at TS and between $-0.07 \%$ and $-0.02 \%$ (mean of $-0.04 \pm 0.02$ 382 \%o) at CR (Table S1).

Despite the lower number of samples at $\mathrm{CR}$, we investigate the $\Delta^{199} \mathrm{Hg} / \Delta^{201} \mathrm{Hg}$ regression 384 slope for each fish feeding pattern in both pristine and gold-mining areas. Slopes of the regression 385 lines are $1.31 \pm 0.06\left(\mathrm{r}^{2}=0.96, \mathrm{n}=16,1 \mathrm{SD}\right)$ and $1.37 \pm 0.09\left(\mathrm{r}^{2}=0.95, \mathrm{n}=15,1 \mathrm{SD}\right)$ for 386 periphytophagous and piscivorous respectively at TS. In the gold-mining area of CR, the regression 387 line slopes are $1.61 \pm 0.34\left(\mathrm{r}^{2}=0.85, \mathrm{n}=6,1 \mathrm{SD}\right)$ and $0.84 \pm 0.12\left(\mathrm{r}^{2}=0.86, \mathrm{n}=10,1 \mathrm{SD}\right)$ for 388 periphytophagous and piscivorous fish respectively. Slopes for periphytophagous fish between TS and 389 390 391

$\mathrm{CR}$ are not significantly different (ANCOVA test, $\mathrm{p}=0.22$ ) while slopes for piscivorous are significantly different (ANCOVA test, $\mathrm{p}=0.002$ ).

\section{Discussion}

\section{1 $\delta^{15} \mathrm{~N}$ and $\delta^{13} \mathrm{C}$ differences between both study locations}

The significantly higher $\delta^{15} \mathrm{~N}$ values measured in periphytophagous fish from TS compared to CR could be explained by difference in the composition of biofilm between both locations. The significantly higher (but slight from an ecological point of view) $\delta^{15} \mathrm{~N}$ values measured in periphytophagous fish from TS compared to CR could be explained by several environmental parameters specific to each site. It could be due, for example, to the difference in the composition and age of the biofilm between both locations (chlorophyll a and $\mathrm{a} / \mathrm{b}$ ratio in periphyton), A variation in periphyton composition could be explained by a difference in transparency of water due to the 
occurrence of suspended particles (which could be linked to the gold mining activity or the soil use) or to the difference in canopy cover over the river (Oyapock river at TS receives less light because of a higher vegetation cover than the Camopi river at the sampling sites). Another explanation for the difference in $\delta^{15} \mathrm{~N}$ measured values in periphytophagous fish between both sites could be linked to the difference in food resources accessibility which may be due to the variation in the vegetation density or in the grazing intensity but also to the different predation pressure on these fish species.

Goix et al. (2019) observed that sediments in TS contained more organic carbon but also more $\mathrm{MeHg}$ (in \%) than in CR. On the contrary, we observed that \% MeHg in periphytophagous fish species is generally lower but more variable at TS than at CR. This suggests that there is not direct exposure route from methylmercury contained in sediments, and that periphytophagous fish contamination is mainly due to trophic transfer. Moreover, the large variation of $\delta^{13} \mathrm{C}$ values of periphytophagous fish at both locations suggests multiple $\mathrm{C}$ sources which will need to be investigated.

\subsection{Total mercury concentrations in fish}

Average total $\mathrm{Hg}$ concentration in fish muscles increased according to the trophic levels. In herbivorous fish species studied, THg concentrations are 125 times lower compared with piscivorous fish species levels. Indeed, herbivorous fish eat terrestrial plants (Planquette et al. 1996) which contain low levels of $\mathrm{Hg}$ and $\mathrm{MeHg}$. Terrestrial plants absorb $\mathrm{Hg}$ from substrate soil (via the roots) and the atmosphere (via the leaves) which are reservoirs of mainly inorganic $\mathrm{Hg}$ species. THg concentrations in the herbivorous fish studied are, thus, much lower than herbivorous fish eating aquatic plants species (Roulet and Maury-Brachet, 2001).

Periphytophagous fish have higher THg concentrations at CR than at TS. As explained in the methods section, periphytophagous fish ingest a mix of bacteria, algae and fungi contained in the biofilm. Inorganic $\mathrm{Hg}$ in the biofilm is methylated into $\mathrm{MeHg}$ subsequently absorbed and bioaccumulated by periphytophagous fish (Guimarães et al., 1998; Acha et al. 2005). The higher THg concentration measured in the periphytophagous fish could result from higher $\mathrm{MeHg}$ concentrations in biofilms at CR (Le Bail et al., 2000). In our previous study, we measured higher THg concentration in 
sediments at CR than at TS. We hypothesize that this THg is first desorbed from sediments and then reached the water column in dissolved form, methylated into the biofilm after its sorption and then ingested by fish (Laperche et al., 2007, Goix et al., 2019).

Piscivorous fish had the same THg concentrations at CR than at TS (Wilcoxon, $\mathrm{W}=65, \mathrm{p}=$ 0.094), while CR is greatly Hg-impacted by goldmining activities. This could not be explained by different size ranges of fish samples (average of $532 \pm 103 \mathrm{~cm}(\mathrm{n}=19)$ and $490 \pm 68 \mathrm{~cm}(\mathrm{n}=11)$ at TS and $\mathrm{CR}$, respectively), nor to differences in their trophic position between both sites. However, the distribution of prey fish depends on several factors such as hydrological characteristics (river size, turbidity and flow, season, etc.), local ecological factors and variability, and fisheries or gold-mining pressures (Maury-Brachet et al., 2020).

\subsection{Hg isotope signatures in relation to the feeding pattern of the fish species}

Very few Hg isotopic studies on river fish flesh have been published. In the Bolivian Amazon, Laffont et al. (2009) analyzed fish from the Beni river and its floodplain lakes. Three other studies have been conducted on river fish by Janssen et al. (2019) in Northeastern USA streams, Donovan et al. (2016) in the Yuba river (California, USA) and Tsui et al. (2012) in the Eel river (California, USA).

The mass dependent isotopic signature, $\delta^{202} \mathrm{Hg}$, for all fish from this study varies between $1.68 \%$ and $-0.89 \%$. This signature is more negative than the ones observed for river fish in literature including the one in the Bolivian Amazon basin. However, $\delta^{202} \mathrm{Hg}$ in sediments is also more negative than the ones in the literature cited in the precedent paragraph. The average Hg isotopic signature from pristine sediments of the Oyapock R. (Goix et al., 2019) were $\delta^{202} \mathrm{Hg}=-2.27 \%$, $\Delta^{199} \mathrm{Hg}=-0.66 \%$ o and $\Delta^{200} \mathrm{Hg}=-0.04 \%$ o $(\mathrm{n}=27)$. Negative $\delta^{202} \mathrm{Hg}, \Delta^{199} \mathrm{Hg}$ and $\Delta^{200} \mathrm{Hg}$ of pristine sediments and soils reflected dry deposition of atmospheric mercury mostly after vegetation uptake by plants and subsequent transfer to the river system (Goix et al., 2019). The MIF of even isotopes is commonly associated with either dry or wet atmospheric deposition that display negative and positive $\Delta^{200} \mathrm{Hg}$, respectively (Fu et al., 2016 and Obrist et al., 2017). Average $\Delta^{200} \mathrm{Hg}$ anomaly close to $-0.05 \%$ measured in fish from the Oyapock basin indicated that $\mathrm{Hg}$ sources for fish is atmospheric $\mathrm{Hg}^{0}$ as observed for sediments. It could be $\mathrm{Hg}$ desorbed and dissolved from sediments and also from 
vegetation (foliage/litter) inputs into the water column (Jiskra et al., 2017; Woerndle et al., 2018). Recent studies monitoring the export of $\mathrm{Hg}$ via streamflow in forested ecosystems have also shown that the majority of $\mathrm{Hg}$ exported was derived from previously dry deposited $\mathrm{Hg}$ in the forested watersheds, as their isotopic signatures resemble those of foliage/litter and forest floor rather than direct precipitation (Tsui et al., 2020).

Following Janssen et al. (2019), Tsui et al. (2012) and Donovan et al. (2016), we applied a $\delta^{202} \mathrm{Hg}$ correction to calculate the $\delta^{202} \mathrm{Hg}$ before isotopic fractionation induced by photochemistry. This calculation has been first made by Gehrke et al. (2011) using experimental relationships to substract the known MDF and MIF that occurs during photochemical degradation and calculating $\Delta^{199} \mathrm{Hg} / \delta^{202} \mathrm{Hg}$ slope to obtain an estimated $\delta^{202} \mathrm{Hg}$ value for prephotodegraded $\mathrm{MeHg}$ and $\mathrm{IHg}$. Actually, we used Bergquist and Blum (2007) experimental data: photoreduction of mercury with $1 \mathrm{mg} / \mathrm{L} \mathrm{C}$ (slope 1.15) and photodemethylation of MeHg with $1 \mathrm{mg} / \mathrm{L} \mathrm{C}$ (slope 2.43) (average $2.7 \mathrm{mg} . \mathrm{L}^{-1}(\mathrm{n}=16)$ of DOC was measured in the study rivers (database of the ANR-RIMNES Research Program)). Assuming that mercury in water column of TS and CR came mainly from sediments, pre-photodegraded mercury has $\Delta^{199} \mathrm{Hg}$ close to the $\Delta^{199} \mathrm{Hg}$ of pristine sediments, the average $\delta^{202} \mathrm{Hg}$ of pre-photodegraded $\mathrm{MeHg}$ is estimated at $-1.54 \%$ and $-1.70 \%$ for piscivorous fish at TS and CR respectively and at $-1.29 \%$ and $1.51 \%$ for periphytophagous fish at TS and CR respectively. These values are much higher than the $\delta^{202} \mathrm{Hg}$ in the pristine sediment $\left(\delta^{202} \mathrm{Hg}=-2.27 \%\right.$ ), suggesting there is a positive offset of around +0.7 \%o (apart from periphytophagous fish from TS) between sediments and fish, consistent with Janssen et al. (2019), Gerhke et al. (2011) and Tsui et al. (2012) observations. This offset is the net result of biotic MDF during IHg methylation (biotic methylation, biotic MeHg degradation, etc.).

The odd-isotopes anomalies of $\mathrm{Hg}$ of periphytophagous fish reflect the isotopic signature of dissolved MeHg. Indeed, the slopes $\left(\Delta^{199} \mathrm{Hg} / \Delta^{201} \mathrm{Hg}\right)$ close to 1.3 have been interpreted as the result of partly photodegraded $\mathrm{MeHg}$ in river water, bioaccumulated by fish (Bergquist and Blum 2007). But the latter slope close to 1 is more likely due to photodegradation of IHg prior to its methylation and ingestion by fish (Bergquist and Blum 2007). The offset of around $-0.2 \%$ observed in $\Delta^{199} \mathrm{Hg}$ between piscivorous and periphytophagous fish for each location could indicate that sources of this $\mathrm{MeHg}$ are 
different for the two fish diets: piscivorous fish are opportunistic hunters and integrate the $\mathrm{Hg}$ signature of the entire environment while periphytophagous are specific biofilm consumers.

Moreover, odd-isotopes anomalies observations point out the fact that both areas have different aquatic processes affecting $\mathrm{Hg}: \Delta^{199} \mathrm{Hg}$ is more positive for periphytophagous fish at $\mathrm{CR}$ and $\Delta^{199} \mathrm{Hg} / \Delta^{201} \mathrm{Hg}$ regression slope at $\mathrm{CR}$ is close to 1 for piscivorous fish. Tsui et al. (2012) observed the same slope for terrestrial predators. According to $\delta^{13} \mathrm{C}$ and $\delta^{15} \mathrm{~N}$ values which are similar between two areas for piscivorous fish, we could suppose that their food sources are quite the same. These observations can only be explained by differences in photochemistry processes between both areas induced by a different water composition, sunlight exposure (canopy coverage), river flow, and others parameters of water dynamic and chemistry.

Consequently, $\mathrm{Hg}$ isotopic signatures in fish are affected by the difference of biotic (methylation/demethylation) and abiotic (photochemistry) processes between both areas. We suppose that both aquatic systems are slightly different as explained before and, moreover, disturbed by goldmining activities by inputs of suspended particles.

\section{Conclusion}

In periphytophagous fish species, THg concentrations were higher in the gold-mining (CR) than in the pristine (TS) area whereas $\delta^{13} \mathrm{C}$ values were enriched and $\delta^{15} \mathrm{~N}$ depleted in CR compared to TS. As these fish exclusively eat biofilm settled on immerged rocks, adventive roots or plant residues, we hypothesize that this difference is due to a different composition of the biofilm between two sites. We showed that $\mathrm{Hg}$ isotopic signatures in fish caught in pristine and gold-mined basins have undergone different speciation processes. Variations in $\mathrm{Hg}$ isotopes fractionation are attributed to: i) the difference in biotic processes and MeHg sources shown by variations of $\delta^{202} \mathrm{Hg}, \delta^{15} \mathrm{~N}$ and $\delta^{13} \mathrm{C}$ in both locations, and ii) variation of abiotic processes such as photochemistry between both areas shown by the difference of odd-isotopes anomalies and $\Delta^{199} \mathrm{Hg} / \Delta^{201} \mathrm{Hg}$ regression slope between fish species and locations. 
To conclude, $\mathrm{Hg}$ isotopic signatures in fish are affected by the difference of biotic (methylation/demethylation) and abiotic (photochemistry) processes between both areas and did therefore not allow to resolve the contribution of gold-mining related liquid $\mathrm{Hg}(0)$ in fish tissues. Mercury isotopes of MeHg in fish and lower trophic level organisms can be complementary to light stable isotope tracers.

\section{Acknowledgements}

This study was funded by the French National Research Agency (ANR-11-CESA-0013, RIMNES Program) and all the analyses were performed in two laboratories of the Midi-Pyrénées Observatory (OMP-GET and ECOLAB) in France. We would like to thank both teams of the HYDRECO laboratory and the Parc Amazonien de Guyane (PAG) for their help during sampling campaigns and the sharing of material devices. We sincerely acknowledge the indigenous communities (Wayãpi and Teko) of the study villages, the doctors from local Health Centers for their kind cooperation during the field work, and the fishermen for sharing their knowledge of the territory. We also thank Marc Pouilly and Fabrice Duponchelle from the French Research Institute for the Development (IRD) for their helpful comments on Amazonian fish behavior and diet. J. Chmeleff is thanked for expert management of the OMP mass spectrometry division in the GET laboratory.

\section{Authors' contribution}

LM was the coordinator of the RIMNES Research Program (funded by the French ANR). LM and RM-B designed the study dedicated to the ichthyologic part of the program. Formal analysis (THg, speciation and $\mathrm{Hg}$ stable isotopes) and geochemical lab work were performed by LL, JM and SGx under the supervision of JS. RR helped with logistics in French Guiana. Fish sampling was realized by RM-B, AL and PG. Statistical analysis were performed by LL and SGx. Funds were acquired by LM and RR. The original draft was written by LL, SGx, JM and LM and revised and edited by all authors. 
Funding: Open access funding provided by the IRD (French Research Institute for Sustainable

Development). This work was supported by the French National Research Agency (ANR-11-CESA0013, RIMNES Program).

Data availability: the online version contains the raw data available in the supplementary material.

\section{Compliance with ethical standards}

Ethical approval: Not applicable.

Consent to participate: Not applicable.

Consent to publish: Not applicable.

Competing interests: The authors declare that they have no known competing financial interests or personal relationships that could have appeared to influence the work reported in this paper.

\section{References}

Acha D., Iñiguez V., Roulet M., Guimarães J. R. D., Luna R., Alanoca L. and Sanchez S. (2005). Sulfate-reducing bacteria in floating macrophyte rhizospheres from an Amazonian floodplain lake in Bolivia and their association with $\mathrm{Hg}$ methylation. Applied and Environmental Microbiology 71: 7531-7535

AMAP/UN Environment. (2019). Technical Background Report for the Global Mercury Assessment 2018. Arctic Monitoring and Assessment Programme, Oslo, Norway/UN Environment Programme, Chemicals and Health Branch, Geneva, Switzerland.

Bergamino, L., Lercari, D., Defeo, O. (2011). Food web structure of sandy beaches: Temporal and spatial variation using stable isotope analysis. Estuar. Coast. Shelf Sci. 91(4): 536-543

Bergquist B. A., and Blum J. D. (2007). Mass-Dependent and -Independent Fractionation of Hg Isotopes by Photoreduction in Aquatic Systems. Science 318: 417-420

Bergquist B. A., and Blum J. D. (2009). The Odds and Evens of Mercury Isotopes: Applications of Mass-Dependent and Mass-Independent Isotope Fractionation. Elements 5: 353-357

Blum J. D. (2011). Applications of stable mercury isotopes to biogeochemistry. In Handbook of Environmental Isotope Geochemistry. Springer 229-245

Blum J. D. and Bergquist B. A. (2007). Reporting of variations in the natural isotopic composition of mercury. Anal. Bioanal. Chem. 388: 353-359 
Blum J. D. Sherman L. S. and Johnson M. W. (2014). Mercury Isotopes in Earth and Environmental

Sciences. Annu. Rev. Earth Planet. Sci. 42: 249-269

Cabana G. and Rasmussen, J. B. (1994). Modelling food chain structure and contaminant bioaccumulation using stable nitrogen isotopes. Nature 372 (6503): 255.

Caut S., Angulo E. and and Courchamp F. (2009). Variation in discrimination factors $(\Delta 15 \mathrm{~N}$ and $\triangle 13 \mathrm{C})$ : the effect of diet isotopic values and applications for diet reconstruction. Journal of Applied Ecology 46 (2): 443-453

Chen C. Y., Borsuk M.E., Bugge D. M., Hollweg T., Balcom P. H., Ward D. M., Williams J. and Mason R. P. (2014). Benthic and Pelagic Pathways of Methylmercury Bioaccumulation in Estuarine Food Webs of the Northeast United States. PLoS ONE 9, e89305.

Cordier S., Grasmick C., Paquier-Passelaigue M., Mandereau L., Weber J.-P. and Jouan M. (1998). Mercury Exposure in French Guiana: Levels and Determinants. Arch. Environ. Health Int. J. 53: 299303

Cordier S., Garel M., Mandereau L., Morcel H., Doineau P., Gosme-Seguret S., Josse D., White R. and Amiel-Tison C. (2002). Neurodevelopmental Investigations among Methylmercury-Exposed Children in French Guiana. Environ. Res. 89: 1-11

Demers J. D., Blum J. D. and Zak D. R. (2013). Mercury isotopes in a forested ecosystem: Implications for air-surface exchange dynamics and the global mercury cycle. Global Biogeochem. Cy. 27 (1): 222-238.

Demers J. D., Sherman L. S., Blum J. D., Marsik F. J. and Dvonch, J. T. (2015). Coupling atmospheric mercury isotope ratios and meteorology to identify sources of mercury impacting a coastal urbanindustrial region near Pensacola, Florida, USA. Global Biogeochem. Cy. 29 (10): 1689-1705.

Donovan P., Blum J. D., Bliss Singer M., Marvin-DiPasquale M. and Tsui M. T. K. (2016). Isotopic composition of inorganic mercury and methylmercury downstream of a historical gold-mining region. Environ. Sci. Technol. 50: 1691-1702

Dominique Y., Muresan B., Duran R., Richard S. and Boudou A. (2007). Simulation of the Chemical Fate and Bioavailability of Liquid Elemental Mercury Drops from Gold Mining in Amazonian Freshwater Systems. Environ. Sci. Technol. 41: 7322-7329

Dominique Y., Maury-Brachet R., Muresan B., Vigouroux R., Richard S., Cossa D., Mariotti A. and Boudou A. (2007). Biofilm and mercury availability as key factors for mercury accumulation in fish (Curimata cyprinoides) from a disturbed Amazonian freshwater system. Environmental toxicology and chemistry/SETAC 26: 45-52.

Dominique Y. (2008). Contamination par les différentes formes chimiques du mercure de la composante biologique du barrage hydroélectrique de Petit-Saut et des zones amont/aval du fleuve Sinnamary, en Guyane française (études in situ et approches expérimentales) 
Durrieu G., Maury-Brachet R. and Boudou A. (2005). Goldmining and mercury contamination of the piscivorous fish Hoplias aimara in French Guiana (Amazon basin). Ecotoxicol. Environ. Saf. 60: 315323

Enrico M., Le Roux G., Marusczak N., Heimburger L-E., Claustres A., Fu X., Sun R. and Sonke J. E. (2016). Atmospheric mercury transfer to peat bogs dominated by gaseous elemental mercury dry deposition. Environ. Sci. Technol. 50: 2405-2412

Estrade N., Carignan J., Sonke J. E. and Donard, O. F. X. (2009). Mercury isotope fractionation during liquid-vapor evaporation experiments. Geochim. Cosmochim. Acta 73: 2693-27113

Fleming E. J., Mack E. E., Green P. G. and Nelson D. C. (2006). Mercury Methylation from Unexpected Sources: Molybdate-Inhibited Freshwater Sediments and an Iron-Reducing Bacterium. Appl. Environ. Microbiol. 72: 457-464

Fréry N., Maury-Brachet R., Maillot E., Deheeger M., De Merona B. and Boudou A. (2001). Goldmining activities and mercury contamination of native Amerindian communities in French Guiana: key role of fish in dietary uptake. Environ. Health Perspect. 109: 449

Fu X., Marusczak N., Wang X., Gheusi F. and Sonke, J. E. (2016). Isotopic composition of gaseous elemental mercury in the free troposphere of the Pic du Midi observatory, France. Environ. Sci. Technol. 50 (11): 5641-5650

Gantner N., Hintelmann H., Zheng W. and Muir D. C. (2009). Variations in stable isotope fractionation of $\mathrm{Hg}$ in food webs of Arctic lakes. Environ. Sci. Technol. 43: 9148-9154

Gentès S., Coquery M., Vigouroux R., Hanquiez V., Allard L. and Maury-Brachet R. (2019). Application of the European Water Framework Directive: Identification of reference sites and bioindicator fishspecies for mercury in tropical freshwater ecosystems (FrenchGuiana). Ecological Indicators. 106. 105468

Gerhke G. E., Blum J. D., Slotton D. G., Greenfield B. K. (2011). Mercury isotopes link mercury in San Francisco Bay forage fish to surface sediments. Environ. Sci. Techno. 45: 1264-1270

Goix S., Maurice L., Laffont L., Rinaldo R., Lagane C., Bosq A., Chmeleff J., Menges J., Heimbürger L. E., Maury-Brachet R. and Sonke J. (2019). A Hg stable isotope study of Hg cycling in the tropical environment and quantification of the gold-mining impact on French Guiana river sediments. Chemosphere 219: 684-694.

Gratz L. E., Keeler G. J., Blum J. D. and Sherman L. S. (2010). Isotopic composition and fractionation of mercury in Great Lakes precipitation and ambient air. Environ. Sci. Technol. 44 (20): 7764-7770

Grimaldi C., Grimaldi M. and Guedron S. (2008). Mercury distribution in tropical soil profiles related to origin of mercury and soil processes. Sci. Total Environ. 401: 121-129

Grimaldi M., Guédron S. and Grimaldi C. (2015). Impact of gold mining on mercury contamination and soil degradation in Amazonian ecosystems of French Guiana. In : Brearley F.Q. (ed.), Thomas 
A.D. (ed.) Land-use change impacts on soil processes : tropical and savannah ecosystems. Wallingford : CABI, 95-107. ISBN 978-1-78064-210-9

Guedron S., Grimaldi C., Chauvel C., Spadini L. and Grimaldi M. (2006). Weathering versus atmospheric contributions to mercury concentrations in French Guiana soils. Appl. Geochem. 21: 2010-2022

Guedron S., Grangeon S., Lanson B. and Grimaldi M. (2009). Mercury speciation in a tropical soil association; Consequence of gold mining on $\mathrm{Hg}$ distribution in French Guiana. Geoderma 153: 331346

Guimarães J. R. D., Meili M., Malm O. and Maria de Souza Brito E. (1998). Hg methylation in sediments and floating meadows of a tropical lake in the Pantanal floodplain, Brazil. Sci. Total Environ. 213: 165-175

Hobson, K. A., Fisk, A., Karnovsky, N., Holst, M., Gagnon, J. M. and Fortier, M. (2002). A stable isotope $(\mathrm{d} 13 \mathrm{C}, \mathrm{d} 15 \mathrm{~N})$ model for the NorthWater food web: implications for evaluating trophodynamics and the flow of energy and contaminants. Deep Sea Res. Part II Top. Stud. Oceanogr. 49 (22e23): 5131e 5150

Jiskra, M., Wiederhold, J.G., Skyllberg, U., Kronberg, R.-M., Kretzschmar, R., 2017. Source tracing of natural organic matter bound mercury in boreal forest runoff with mercury stable isotopes. Environ. Sci.: Processes Impacts 19, 1235-1248.

Keith, P., Persat, H., Feunteun, E. and Allardi, J. (2011). Les Poissons d'eau douce de France. Collection Inventaires \& biodiversité. Biotope Editions, Publications scientifiques du Muséum 552 (in French)

Kerin E. J., Gilmour C. C., Roden E., Suzuki M. T., Coates J. D. and Mason R. P. (2006). Mercury Methylation by Dissimilatory Iron-Reducing Bacteria. Appl. Environ. Microbiol. 72: 7919-7921

Klaus, J. E., Hammerschmidt, C. R., Costello, D. M., Burton, G. A. (2016). Net methylmercury production in 2 contrasting stream sediments and associated accumulation and toxicity to periphyton. Environ. Toxicol. Chem. 35(7), 1759-1765

Kwon S. Y., McIntyre P. B., Flecker A. S. and Campbell L. M. (2012a). Mercury biomagnification in the food web of a neotropical stream. Sci. Total Environ. 417-418: 92-97

Kwon S. Y., Blum J. D., Carvan M. J., Basu N., Head J. A., Madenjian C. P. and David S. R. (2012b). Absence of Fractionation of Mercury Isotopes during Trophic Transfer of Methylmercury to Freshwater Fish in Captivity. Environ. Sci. Technol. 46: 7527-7534

Laffont L., Sonke J. E., Maurice L., Hintelmann H., Pouilly M., Sánchez Bacarreza Y., Perez T. and Behra P. (2009). Anomalous mercury isotopic compositions of fish and human hair in the Bolivian Amazon. Environ. Sci. Technol. 43: 8985-8990 
Laffont L., Sonke J. E., Maurice L., Monrroy S. L., Chincheros J., Amouroux D. and Behra P. (2011). Hg Speciation and Stable Isotope Signatures in Human Hair As a Tracer for Dietary and Occupational Exposure to Mercury. Environ. Sci. Technol. 45: 9910-9916

Lamberti, G. A. (1996). The role of periphyton in benthic food webs. Algal ecology

Laperche V., Maury-Brachet R., Blanchard F., Dominique Y., Durrieu G., Massabuau J. C., Bouillard H., Joseph B., Laporte P., Mesmer-Dudons N., Duflo V. et Callier L. (2007). Répartition régionale du mercure dans les sédiments et les poissons de six fleuves de Guyane: Rapport BRGM/RP55965FR, 203.

Layman C. A., Araujo M. S., Boucek R., Hammerschlag- Peyer C. M., Harrison E., Jud Z. R., Matich P., Rosenblatt A. E., Vaudo J. J., Yeager L. A., Post D. M. and Bearhop S. (2012). Applying stable isotopes to examine food- web structure: an overview of analytical tools. Biological Reviews 87 (3): $545-562$

Le Bail, P.-Y., Covain, R., Jégu, M., Fisch-Muller, S., Vigouroux R. and Keith, P. (2012). Updated checklist of the freshwater and estuarine fishes of French Guiana. Cybium 36 (1): 293-319.

Le Bail, P. Y., Keith, P. and Planquette, P. (2000). Atlas des poissons d'eau douce de Guyane ; Tome 2, fascicule II: Siluriformes. Patrimoines naturels (MNHN/SPN), 43, 307. Paris (in French).

Lee, C. C. (2005). Environmental Engineering Dictionary (Government Institutes)

Lepak R., Yin R., Krabbenhoft D. P., Ogorek J. M., DeWild J. F., Holsen T. M. and Hurley J. P. (2015). Use of stable isotope signatures to determine mercury sources in the Great Lakes. Environ. Sci. Technol. Lett. 2 (12): 335-341

Marshall B. G., Veiga M. M., Kaplan R. J., Adler Miserendino R., Schudel G., Bergquist B. A., Guimarães J. R. D., Sobrald L. G. S. and Gonzalez-Mueller C. (2018). Evidence of transboundary mercury and other pollutants in the Puyango-Tumbes River basin, Ecuador-Peru. Environ. Sci.: Processes Impacts. 20: 632-641

Masbou J. (2014). Etude des processus metaboliques, ecologiques et biogeochimiques controlant le fractionnement isotopique du $\mathrm{Hg}$ chez les mammiferes marins de l'Arctique. $\mathrm{PhD}$ dissertation, Université Toulouse Paul Sabatier, pp 275

Masbou J., Point D. and Sonke J. E. (2013). Application of a selective extraction method for methylmercury compound specific stable isotope analysis (MeHg-CSIA) in biological materials. J. Anal. At. Spectrom. 28: 1620

Mason R. P., Reinfelder J. R. and Morel F. M. M. (1995). Bioaccumulation of mercury and methylmercury. Water. Air. Soil Pollut. 80: 915-921

Maurice L., Goix S., Laffont L., Sonke J. E., Maury-Brachet R., Lagane C., Bosq A., Candaudap F. and Rinaldo R. (2014). Hg stable isotope as a tracer of gold mining activities in the Oyapock river basin, French Guiana. In: 17th ICHMET International Conference on Heavy Metals in the Environment, Sept. 2014, Guiyang, China. 
Maurice-Bourgoin L., Quiroga I., Chincheros J. and Courau P. (2000). Mercury distribution in waters and fishes of the upper Madeira rivers and mercury exposure in riparian Amazonian populations. Sci. Total Environ. 260: 73-86

Maurice-Bourgoin L., Quiroga I., Guyot I. L. and Malm O. (1999). Mercury Pollution in the Upper Beni River Basin Bolivia. Ambio 28: 302-306

Maury-Brachet R., Durrieu G., Dominique Y. and Boudou A. (2006). Mercury distribution in fish organs and food regimes: Significant relationships from twelve species collected in French Guiana (Amazonian basin). Sci. Total Environ. 368: 262-270

Maury-Brachet R., Gentes S., Dassié E. P., Feurtet-Mazel A., Vigouroux R., Laperche V., Gonzalez P., Hanquiez V., Mesmer-Dudons N., Durrieu G. and Legeay A. (2020). Mercury contamination levels in the bioindicator piscivorous fish Hoplias aïmara in French Guiana rivers: mapping for risk assessment. Environ Sci Pollut Res 27: 3624-3636

Meech J. A., Veiga M. M. and Tromans D. (1997). Emission and Stability of Mercury in the Amazon. Can. Metall. Q. 36: 231-239

Mergler, D.; Anderson, H. A.; Chan, L. H. M.; Mahaffey, K. R.; Murray, M.; Sakamoto, M.; Stern, A. H. (2007). Methylmercury exposure and health effects in humans: A worldwide concern. Ambio 36: $3-11$

Monperrus M., Rodriguez-Gonzalez P., Amouroux D., J. Garcia Alonso I. and Donard O. F. X. (2008). Evaluating the Potential and Limitations of Double-Spiking Species-Specific Isotope Dilution Analysis for the Accurate Quantification of Mercury Species in Different Environmental Matrices. Analytical and Bioanalytical Chemistry 390 (2): 655-666

De Morais L. T. and Raffray J. (1999). Movements of Hoplias aimara during the filling phase of the Petit-Saut dam, French Guyana. J. Fish Biol. 54: 627-635

Navarro P., Clémens S., Perrot V., Bolliet V., Tabouret H., Guérin T., Monperrus M. and Amouroux D. (2011). Simultaneous determination of mercury and butyltin species using a multiple speciesspecific isotope dilution methodology on the European, Anguilla anguilla glass eel and yellow eel. International Journal of Environmental Analytical Chemistry. 1-17

Neres- Lima V., Machado- Silva F., Baptista D. F., Oliveira R. B. S., Andrade P. M., Oliveira A. F., Sasada- Sato C. Y., Silva- Junior E. F., Feijó- Lima R., Angelini R., Camargo P. B. and Moulton T.P. (2017). Allochthonous and autochthonous carbon flows in food webs of tropical forest streams. Freshwater Biology 62 (6): 1012-1023

Obrist D., Agnan Y., Jiskra M., Olson C. L., Colegrove D. P., Hueber J., Moore C. W., Sonke J. E. and Helmig D. (2017). Tundra uptake of atmospheric elemental mercury drives Arctic mercury pollution. Nature. 547 (7662): 201-204 
Pacyna E. G., Pacyna J. M., Sundseth K., Munthe J., Kindbom K., Wilson S., Steenhuisen F. and Maxson P. (2010). Global emission of mercury to the atmosphere from anthropogenic sources in 2005 and projections to 2020. Atmos. Environ. 44: 2487-2499

PAG, Suivi environnemental des impacts de l’orpaillage illégal. 2017 Bulletin n ${ }^{\circ 5} 5 \mathrm{p}$.

Perrot V., Epov V. N., Pastukhov M. V., Grebenshchikova V. I., Zouiten C., Sonke J. E., Husted S., Donard O. F. X. and Amouroux D. (2010). Tracing sources and bioaccumulation of mercury in fish of Lake Baikal- Angara River using Hg isotopic composition. Environ. Sci. Technol. 44: 8030-8037

Perrot V., Pastukhov M. V., Epov V. N., Husted S., Donard O. F. X. and Amouroux D. (2012). Higher Mass-Independent Isotope Fractionation of Methylmercury in the Pelagic Food Web of Lake Baikal (Russia). Environ. Sci. Technol. 46: 5902-5911

Peterson, B. J., Fry, B. (1987). Stable isotopes in ecosystem studies. Annu. Rev. Ecol. Syst. 18: 293320

Pfeiffer W. C. and de Lacerda L. D. (1988). Mercury inputs into the Amazon Region, Brazil. Environ. Technol. Lett. 9: 325-330

Planquette P., Keith P. and Le Bail P-Y. (1996). Atlas des poissons d'eau douce de Guyane. Museum d'Histoire Naturelle. Paris

Post D. M. (2002). Using stable isotopes to estimate trophic position: models, methods, and assumptions. Ecology 83: 703-718

Post, D. M., Layman, C. A., Arrington, D. A., Takimoto, G., Quattrochi, J., Montana, C. G. (2007). Getting to the fat of the matter: models, methods and assumption for dealing with lipids in stable isotope analyses. Oecologia. 152: 179-189

Pouilly M., Rejas D., Perez T., Duprey J-L., Molina C. I., Hubas C. and Guimarães J. R. D. (2013). Trophic structure and mercury biomagnification in tropical fish assemblages, Itenez River, Bolivia. PLoS ONE 8(5): e65054

Rahm M., Thibault P., Shapiro A., Smartt T., Paloeng C., Crabbe S., Farias P., Carvalho R., Joubert P. (2017). Monitoring the impact of gold mining on the forest cover and freshwater in the Guiana Shield. Reference year 2015. REDD+ for the Guiana Shield Project and WWF Guianas. Report pp.20

Rimbaud D., Restrepo M., Louison A., Boukhari R., Ardillon V., Carles G., Lambert V. and Jolivet A. (2017). Blood lead levels and risk factors for lead exposure among pregnant women in western French Guiana: the role of manioc consumption. Journal of Toxicology and Environmental Health, Part A, DOI: $10.1080 / 15287394.2017 .1331490$

Roulet M., Lucotte M., Canuel R., Rheault I., Tran S., De Freitos Gog Y.G., Farella N., Souza do Vale R., Sousa Passos C. J., Jesus da Silva E., Mergler D. and Amorim M. (1998). Distribution and partition of mercury in waters of Tapajos. Sci. Total Environ. 213: 203-2011 
Roulet M., Lucotte M., Guimarães J. R. D. and Rheault I. (2000). Methylmercury in water, seston, and epiphyton of an Amazonian river and its floodplain, Tapajos River, Brazil. Sci. Total Environ. 261: 43-59

Roulet M., Guimaraes J. R. D. and Lucotte M. (2001). Methylmercury production and accumulation in sediments and soils of an Amazonian floodplain-effect of seasonal inundation. Water. Air. Soil Pollut. 128: 41-60

Roulet M. and Maury-Brachet R. (2001). Le mercure dans les organismes aquatiques amazoniens. In Le mercure en Amazonie. IRD Editions

Senn D. B., Chesney E. J., Blum J. D., Bank M. S., Maage A. and Shine J. P. (2010). Stable Isotope (N, C, Hg) Study of Methylmercury Sources and Trophic Transfer in the Northern Gulf of Mexico. Environ. Sci. Technol. 44: 1630-1637

Smith R. S., Wiederhold J. G., Jew A. D., Brown G. E., Bourdon B. and Kretzschmar R. (2014). Small-scale studies of roasted ore waste reveal extreme ranges of stable mercury isotope signatures. Geochim. Cosmochim. Acta 137: 1-17

Sonke, J. E., (2011). A global Hg isotope box-model for mass-independent Hg isotope fractionation. . Geochim. Cosmochim. Acta 75: 4577-4590

Sonke, J. E. and Blum, J. D. (2013). Advances in mercury stable isotope biogeochemistry. Chemical Geology 336: 1-4

Telmer K., Costa M., Simões Angélica R., Araujo E. S. and Maurice Y. (2006). The source and fate of sediment and mercury in the Tapajós River, Pará, Brazilian Amazon: Ground- and space-based evidence. J. Environ. Manage. 81: 101-113

Tsui M. T. K., Blum J. D., Kwon S. Y., Finlay J. C., Balogh S. J. and Nollet Y. H. (2012). Sources and Transfers of Methylmercury in Adjacent River and Forest Food Webs. Environ. Sci. Technol. 46: 10957-10964.

Tsui, M.T.K., Blum, J.D., Finlay, J.C., Balogh, S.J., Kwon, S.Y., Nollet, Y.H., 2013. Photodegradation of methylmercury in stream ecosystems. Limnol. Oceanogr. 58, 13-22.

Tsui M. T. K., Blum J. D. and Kwon S. Y. 2020. Review of stable mercury isotopes in ecology and biogeochemistry. Science of the Total Environment. 716: 135386

US Environmental Protection Agency. (2012). https://www.epa.gov/fish-tech/epa-fda-fish-advicetechnical-information

Vander Zanden, J. and Rasmussen, J.B. (1996). A trophic position model of pelagic food webs: impact on contaminant bioaccumulation in lake trout. Ecol. Monogr. 66 (4): $451 \mathrm{e} 477$

Velásquez-López, P. C. (2010). Mercury in artisanal and small scale gold mining: identifying strategies to reduce environmental contamination in Southern Ecuador. University of British Columbia. doi:10.14288/1.0071256 
Woerndle, G.E., Tsui, M.T.K., Sebestyen, S.D., Blum, J.D., Nie, X., Kolka, R.K., 2018. New insights on ecosystem mercury cycling revealed by stable isotopes of mercury in water flowing from a headwater peatland catchment. Environ. Sci. Technol. 52, 1854-1861.

World Wildlife Founds. (2018). Lutte contre l'Orpaillage Illégal en Guyane; orientations pour une

911 https://www.wwf.fr/sites/default/files/doc-

Historical records of mercury stable isotopes in sediments of Tibetan Lakes. Sci. Rep. 6: 23332 